Comparison of different methods of calculation of FTI

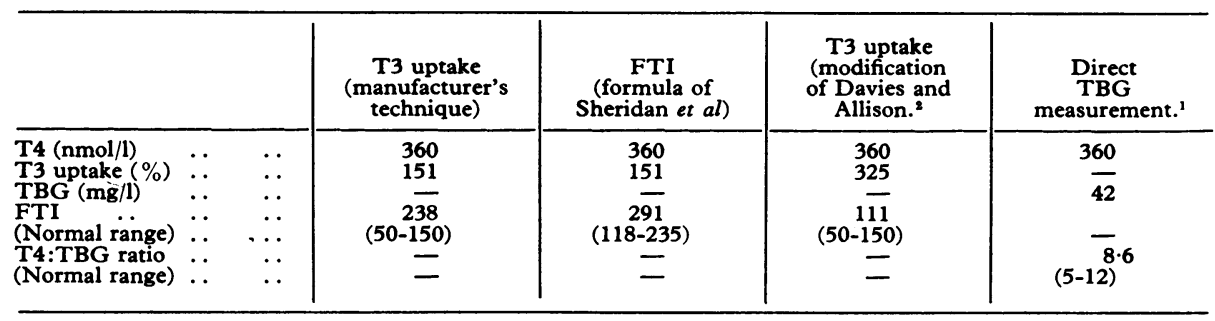

Conversion: SI to traditional units-T4: $1 \mathrm{nmol} / 1 \simeq 0.08 \mu \mathrm{g} / 100 \mathrm{ml}$

hormone binding capacity is more likely to improve the situation than any simple formula. The report.correctly suggests that in euthyroid patients serum thyroxine (T4) levels approaching zero are not associated with Thyopac-3 values below $50 \%$. This may be because the resin does not take up all unbound triiodothyronine (T3), but in any case the problem can easily be resolved by taking a $1-\mathrm{ml}$ aliquot from an unused vial as a zero standard.

Direct assay of the serum thyroxinebinding globulin (TBG) ${ }^{1}$ or our own modification of the Thyopac-3 test, reported in this journal last year, ${ }^{2}$ seems likely to result in clinically more meaningful FTIs than the new formula. Results shown in the table above clearly indicate the marked clinically important differences of FTIs calculated according to (1) the manufacturer's instructions; (2) the formula of Dr Sheridan and his colleagues (3) our modified T3 uptake test $;^{2}$ and (4) the T4:TBG ratio. ${ }^{1}$ The patient, a man aged 57 , is considered clinically euthyroid. His plasma protein-bound iodine concentration on two occasions in 1973 was found to be 1434 and $1277 \mathrm{nmol} / 1(18 \cdot 2$ and $16 \cdot 2 \mu / 100 \mathrm{ml}$ ) (norma range $315-630 \mathrm{nmol} / \mathrm{l}(4-8 \mu \mathrm{g} / 100 \mathrm{ml})$. After 1973 repeated tests showed marked elevation of serum T4 and T3 uptake. The results in the table are of tests carried out in 1978.

The best measure may well be the unbound thyroid hormones, but in the meantime it is the $\mathrm{T} 3$ uptake which requires attention, not the FTI.

\section{C Davies}

H ALlisoN

Pathology Laborator

Leighton Hospital

Crewe, Cheshire 1 Burr, W A, et al, British Medical fournal, 1977, 1, 485.
Davies, M C, and Allison, H, British Medical fournal, $1977,2,128$

\section{Labetalol in hypertensive emergencies}

SIR,-The report by Dr R R Ghose and others indicating the value of oral labetalol in hypertensive emergencies ( 8 July, p 96) is of considerable interest to us. We have recently been using labetalol in drug trials at this hospital, and have attempted to define situations where labetalol would have particular clinical advantages. Experience so far indicates that, used in conjunction with a diuretic, labetalol has a powerful antihypertensive effect, particularly in the erect position and sometimes with distressing postural hypotension.

As a result of our initial clinical experience we decided to use labetalol for managing severe tetanus in the intensive care unit in an attempt to block the sympathetic overactivity which produces tachycardia and acute hypertension in this condition. This drug has theoretical advantages over propranolol because, in addition to its beta-blocking activity, the $\alpha$-adrenergic blocking effect could be of particular importance in preserving renal and cerebral blood flow and in helping to produce a more rapid lowering of blood pressure.

A 16-year-old boy with tetanus was treated with $50 \mathrm{mg}$ labetalol eight hourly by mouth. His blood pressure fell from an initial value of $180 / 130 \mathrm{~mm} \mathrm{Hg}$ to $150 / 110 \mathrm{~mm} \mathrm{Hg}$ in four hours; then 12 hours after administering the first dose it fell to $80 / 60 \mathrm{~mm} \mathrm{Hg}$. The pulse rate was reduced from 128 beats $/ \mathrm{min}$ to 104 beats/min at four hours and 96 beats/min at 12 hours.

Our conclusions are that the drug is of value for lowering severely raised blood pressures and can be used in emergencies but that its action when administered orally is slow and that $\alpha$-adrenergic blockade is more striking than beta-blockade. In tetanus, this may be especially important, in view of a recent case report by Dr N Buchanan and others (22 July, p 254) showing that selective $\beta$-adrenergic blockade may carry a possible risk of acute left ventricular failure and pulmonary oedema in severe tetanus. It was postulated that the myocardium, impaired by toxic damage, ${ }^{3}$ probably requires some sympathetic drive for maintaining a satisfactory cardiac output in these patients. A drug which is predominantly alpha-blocking, but also produces some betablocking activity, may be of specific value in the hypertensive crisis which occurs in severe tetanus.

\section{Department of Anaesthetics
and Intensive Care, and}

Wadia HaNNA

Department of Medicine,

University of the West Indies, Kingston, Jamaica

${ }^{1}$ Keilty, S R, et al, Lancet, 1968, 2, 195.

2 Buchanan, N, et al, British Medical fournal, 1978, 2 254.
1, 540.

SIR,-In reply to Drs C G H Maidment and Roy Davies (19 August, p 566) only five patients with severe hypertension defined by a diastolic blood pressure exceeding $130 \mathrm{~mm} \mathrm{Hg}$ and a grade 3 or 4 fundus were treated immediately on admission to the ward. The remaining six patients were observed for about four hours until we were satisfied that they had severe "fixed" hypertension. If the diastolic pressure fell below this figure during this observation period the patient became ineligible for treatment as described. The one exception, a patient with encephalopathy, was admitted with diastolic pressure below $130 \mathrm{~mm}$ $\mathrm{Hg}$ but the pressure rose above this figure before treatment. Difficulties in separating fixed from labile hypertension are considerable.
The Oxford continuous recorder was unable to make this differentiation after monitoring all grades of severity of untreated hypertension over 48 hours. ${ }^{1}$

The suggestion that fixed hypertension characterised by a diastolic pressure of 130 $\mathrm{mm} \mathrm{Hg}$ or above and grade 1 or 2 fundus does not merit prompt antihypertensive therapy is questionable. In a similar study from Glasgow 16 patients with severe hypertension were treated with intravenous labetalol, and only four patients had grade 3 or 4 fundi. The phrase "hypertensive emergency" appeared in discussion. ${ }^{2}$ All patients in our study had been referred from general practice with varying degrees of headache. Control observations were not made, but we believe that reduction of blood pressure with oral labetalol, which has a faster action than beta-blockade alone, is an effective treatment.

R R GHOSE

W D MORGAN

Singleton Hospital

Swansea

${ }^{1}$ Goldberg, A D, et al, British Heart fournal, 1978, 40,

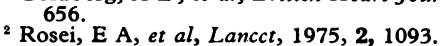

\section{Pre-employment medical examinations}

SIR,-You have previously published letters from me and others drawing attention to the futility of medical examinations as a preliminary to acceptance in companies' sick pay and superannuation schemes and to the injustice to individuals which from time to time results therefrom. A case recently reported in the lay press shows that this practice is still continuing, and the doctor who rejected an applicant for employment is reported as saying he had done so because the company operated a generous sick pay scheme.

It would be wrong to comment on a particular case on the basis of a press report; but it is time that the following facts were recognised both by examining doctors and by those employing authorities whom they advise.

(1) The pre-employment examination has no predictive value in indicating an employee's future sickness absence. This view is generally accepted by experienced occupational physicians and has been amply confirmed by Taylor in a series of studies of oil refinery workers over a period of eight years. ${ }^{1-3}$

(2) If length of survival could be predicted on the basis of a single routine examination many pension schemes making "Al fitness" a criterion for admission would be insolvent because of the number of long-livers drawing their pensions for a quarter-century or more after retirement. That this has not happened is sufficient evidence that the ritual examination is valueless in this context. Moreover, an employee dying before retirement costs the pension scheme only an amount proportional to his contributions-is it right to refuse him employment if he is capable of doing the job satisfactorily meanwhile?

(3) There is a case for pre-employment examination for certain jobs making heavy physical demands, calling for particular qualities, or entailing exposure to (some) toxic hazards. This is a quite separate question, and the vast majority of jobs in British industry and commerce are not in these categories.

The Health and Safety at Work Act has led to an increased demand from employers 
for skilled advice on occupational health matters, and in consequence many previously neglected environmental problems have come to light which call for medical help. It is the duty of those who undertake to advise them to make it plain that these are the importan tasks, and that occupational medicine does not consist of routine examinations of new employees on the pretence that the doctor can forecast future sickness absence experience or survival.

Bettws Newydd,
Usk, Gwent

F H TYRER

Taylor, P J, British fournal of Industrial Medicine, 1967, 24, 93 and 169

${ }^{2}$ Taylor, $\mathbf{P}$ J, British fournal of Industrial Medicine, $1968,25,106$.

Taylor, P J, Transactions of the Society of Occupational Medicine, 1968, 18, 96.

\section{Uniform style for biomedical journals}

SIR,-The decision of the International Steering Committee of Medical Editors (20 May, p 1334) to recommend the adoption of the style of abbreviations of names of journals as used in Index Medicus will be welcomed by most medical librarians, as this decision follows the recommendations of the Library Association Medical Section. ${ }^{1}$ May I, however, point out a current trend which is rather disturbing?

The redesign of journal covers, in line with modern design practice, often gives prominence to the initial letters of the title. The example known to most of us is the fournal of the American Medical Association (known almost everywhere as $\mathcal{F} A M A$ ). Thus the current list of journals indexed in Index Medicus $^{2}$ includes, as well as JAMA, the following: AJR, JAOA, JCU, JNM, JOM, and so on, but the most striking example is that two journals are listed as ZFA (Dresden) and ZFA (Stuttgart), where the $A$ is not even the abbreviation for the same word.

The adoption of an international standard for the abbreviation of titles of periodicals is highly desirable, and was pioneered by the British Medical fournal with its compilation of World Medical Periodicals, ${ }^{3}$ now sadly out of date. The scheme used by the Nationa Library of Medicine for Index Medicu follows very closely ISO-4-1972,4 with the exceptions noted above, but I wonder how long it will be before it is reduced to a set of incomprehensible initials.

\section{J WRIGHT}

BMA House,

Deputy librarian, BMA

\section{${ }^{1}$ Library Association Medical Section, Reference Citation Recommendations. London, Library Association, 1972 \\ United States National Library of Medicine, List of fournals Indexed in Index Medicus. DHEW Publica- tion No (NIH) 78-267. \\ Printing OfHice, 1978.
Fleurent, C H A, (editor), World Medical Periodicals, 3rd edn. New York, World Medical Association, 1961 \\ International Standards Organisation, International Standard ISO-4-1972 (E). Documentation-Inter national Code for the Abbreviation of Titles of Periodicals. Geneva, ISO, 1972.}

\section{Axillary hyperhidrosis}

SIR,-Dr David Bird's helpful letter (29 July, p 357) adds a further five patients to the lengthening list of cases of axillary hyperhidrosis whose distressing symptoms have been eliminated by the use of a modification of the regimen originally reported by Hurley and Shelley. ${ }^{1}$

I write only to amplify a sentence of $\mathrm{Dr}$ Bird which I think might perhaps mislead. He suggested: "It is too soon to abandon surgery completely since the long-term results of thi topical treatment are not known." He clearly refers to the possibility of loss of effect of the aluminium chloride hexahydrate preparation with the passage of time. Although we considered it too early to include it in our paper, the average time between treatments in our patients has steadily lengthened, so that an increasing number now have to make applications only once every two to three weeks.

\section{$\mathrm{K} \mathrm{T}$ SCHOLES}

Princess Margaret Hospital, Swindon Hurley, H J, and Shelley, W B, fournal of the American
Medical Association, 1963, 186, 109.

\section{Dangers of glass doors}

Sir, - I have just come across yet another incident of an extremely serious injury involving a glass door. One wonders whether the aesthetic value of such doors justifies the injuries that occasionally occur. It seems to me that it ought to be illegal to use full length glass doors, screens, or windows without a horizontal dividing or preventive bar, strong enough to take the weight of a fairly heavy person falling against it. An alternative would be to use armoured glass.

A J PIM

Nettlebed,
Henley on Thames

\section{Atenolol self-poisoning}

SIR,-The recent reports provide severa examples of self-poisoning with $\beta$-adrenoceptor blocking agents. The outcome of these cases has varied from being relatively uncomplicated $^{1}$ to fatal. ${ }^{2}$ The opinion that these agents, even in massive overdosage, represen little hazard to the normal healthy subject whose myocardial performance is not dependent on sympathetic drive has already been expressed. ${ }^{3}$ We therefore consider it of interes to report what we believe is the first recorded case of atenolol self-poisoning in a patien with normal cardiac function.

The patient, a 24-year-old woman with a psychiatric history, was being treated for hypertension secondary to chronic pyelonephritis. In recent months her blood pressure had been well controlled on a combination of clonidine and atenolol. A recent assessment of her renal and cardiac function (including serum urea, electrolyte, and creatinine estimations and electrocardiography) showed nothing abnormal. In attempting suicide she took about $1200 \mathrm{mg}$ of atenolol, the number of tablets being reliably confirmed by a relative who was familiar with he treatment and her current supply. later, her general condition was very good. Her tion. Of the four postvaccination serum pulse rate was 80 beats/minute, with a recumbent blood pressure of $150 / 110 \mathrm{~mm} \mathrm{Hg}$. There were no signs of cardiac decompensation. None of the tablets were recovered from the gastric contents on lavage. She was closely monitored over the ensuing days both clinically and electrocardiographically, during which time her pulse rate varied between 66 and 80 beats/minute in sinus rhythm. Renal function remained normal. With the temporary withdrawal of all medication, however, her blood pressure rose gradually, reaching $190 / 120 \mathrm{~mm} \mathrm{Hg}$ five days later. Control was then re-established with a combination of atenolol and prazosin. Her further clinical course was uncomplicated.

In addition to normal myocardial function, other features are worthy of mention. Although tolerance to most beta-blockers is very variable, atenolol has a much narrower effective dose range. ${ }^{4}$ Doses over the average $100-200 \mathrm{mg} /$ day regimen, although further affecting pulse rate, do not confer any additional benefit in hypertension. Large doses of atenolol have been well tolerated by volunteers, ${ }^{4}$ after gradual titration, and perhaps the existing beta-blockade in our patient conferred a similar protective titrating effect.

F L J SHanahan T B COUNIHAN

Mater Misericordiae Hospital

and University College,

1 Wermut, W, and Wojcicki, M, British Medical

Khan, A, and Muscat-Baron, J M, British Medical fournal, 1977, 1, 552 .

Boakes, A J, and Boeree, B H, British Medical fournal, $1973,4,675$

Zacharias, F J, and Cowen, K J, Postgraduate Medical
尹ournal, 1977, 53, suppl No 3, p 111 Fournal, 1977, 53, suppl No 3, p 111

Postgraduate Medical fournal, 1977, 53, suppl Jo 3 , p 114.

\section{Efficacy of rubella vaccination}

SIR,-The timely letter from Dr W J C Roberts on the efficacy of rubella vaccination (5 August, p 433) reminds us that not all women shown by laboratory tests to be susceptible to rubella develop rubella haemagglutination-inhibiting (HI) antibodies after vaccination. Unfortunately he does not name the vaccine he used or the dilution of the patients' serum without antibody which indicated susceptibility. If facilities are available we would support his suggestion of testing a postvaccination serum sample and revaccination if the patient has not developed antibodies.

In some maternity units in this area postnatal rubella vaccination with Cendevax is offered to patients if previous laboratory tests have shown that they are susceptible to rubella. A serum sample is collected approximately eight weeks after vaccination (unfortunately this period varies with circumstances), and the pre- and post-vaccination serum samples are tested in parallel for rubella antibodies. The table shows that during the period February 1977 to March $78.9 \%$ of women with a titre of Fournal, 1973, 3, 591

Post-vaccination rubella $H I$ antibodies in serum from 82 women with titres $<1 / 8$ who were vaccinated with Cendevax

\begin{tabular}{|c|c|c|c|c|c|c|c|c|c|}
\hline \multirow{2}{*}{$\begin{array}{l}\text { No } \\
\text { tested }\end{array}$} & \multirow{2}{*}{$\begin{array}{l}\text { Weeks after vaccination } \\
\text { when serum was } \\
\text { collected }\end{array}$} & \multicolumn{8}{|c|}{ Post-vaccination rubella $\mathrm{HI}$ antibody titres } \\
\hline & & $<1 / 8$ & $1 / 8$ & $1 / 16$ & $1 / 32$ & $1 / 64$ & $1 / 128$ & $1 / 256$ & $1 / 512$ \\
\hline $\begin{array}{l}62 \\
20\end{array}$ & $\begin{array}{c}5-9(\text { mean } 7) \\
\geqslant 10(\text { mean } 22)\end{array}$ & -4 & $\begin{array}{l}1 \\
2\end{array}$ & $\begin{array}{l}4 \\
3\end{array}$ & $\begin{array}{r}16 \\
5\end{array}$ & $\begin{array}{l}25 \\
6\end{array}$ & $\begin{array}{r}10 \\
1\end{array}$ & 2 & $\overline{1}$ \\
\hline
\end{tabular}

